\title{
Conservation of endangered galaxiid fishes in the Falkland Islands requires urgent action on invasive brown trout
}

\author{
J. F. Minett ${ }^{1}$, D.M. Fowler ${ }^{1}$, J.A.H. Jones ${ }^{1}$, P. Brickle ${ }^{2}$, G.T. Crossin ${ }^{3}$, S. Consuegra ${ }^{1}$, \\ C. Garcia de Leaniz ${ }^{1 *}$
}

${ }^{1}$ Swansea University, CSAR, Swansea SA2 8PP, UK

${ }^{2}$ South Atlantic Environmental Research Institute, Stanley, Falkland Islands

${ }^{3}$ Department of Biology, Dalhousie University, Halifax, Nova Scotia, B3H 4R2 Canada

*corresponding author: c.garciadeleaniz@swansea.ac.uk

Keywords: Invasive species, translocations, risk management, invasion risk competitive exclusion 


\begin{abstract}
Non-native salmonids are protected in the Southern hemisphere where they sustain aquaculture and valuable sport fisheries, but also impact on native galaxiid fishes, which poses a conservation conundrum. Legal protection and human-assisted secondary releases may have helped salmonids to spread, but this has seldom been tested. We reconstructed the introduction of brown trout (Salmo trutta) to the Falkland Islands using historical records and modelled its dispersal. Our results indicate that establishment success was $~ 88 \%$, and that dispersal was facilitated by proximity to introduction sites and density of stream-road crossings, suggesting it was human assisted. Brown trout has already invaded $54 \%$ of Falkland rivers, which are 2.9-4.5 times less likely to contain native galaxiids than uninvaded streams. Without strong containment we predict brown trout will invade nearly all suitable freshwater habitats in the Falklands within the next $\sim 70$ years, which might put native freshwater fishes at a high risk of extinction.
\end{abstract}




\section{Introduction}

Invasive species represent one of the major threats to freshwater biodiversity, and yet their introduction has in many cases been intentional. For example, salmonids have been deliberated translocated all over the world to provide fishing and aquaculture opportunities since the $19^{\text {th }}$ century (McDowall 2006), despite being responsible for the demise of native fish fauna (Garcia de Leaniz et al. 2010; Young et al. 2010).

Human activities have not only been responsible for the introduction of invasive species, but have also helped in many cases with their expansion (Hulme 2015). Yet, the importance of human assisted dispersal of non-native species is often difficult to assess due to lack of accurate introduction records and confounding environmental factors (Tabak et al. 2017). Islands provide ideal scenarios to examine the dispersal of invasive species because the date and location of introductions are typically well known, and there is often baseline information on the status of native species before the invasion (Ewel and Högberg 1995) .

Brown trout (Salmo trutta) is one of the most successful freshwater invaders and has been included as one of the ' 100 of the world's worst invasive alien species' (Lowe et al. 2000) due to its widespread ecological damage. The species has been implicated in the decline of native galaxiid fishes in many parts of the Southern hemisphere (McDowall 2006), most notably in South America (Elgueta et al. 2013; Young et al. 2010), New Zealand (McDowall 2003), and the Falkland Islands, where it has benefitted from protected status (McDowall et al. 2001). This has created a conservation conundrum because protecting non-native salmonids to boost sport fishing may have put native fish at risk (Garcia de Leaniz et al. 2010).

Three surveys, conducted 10 and 20 years ago, concluded that brown trout had severely impacted two of the three native galaxiids, Aplochiton zebra and Aplochiton taeniatus (Fowler 2013; McDowall et al. 2001; Ross 2009), which appear to have contracted their range and are threatened by secondary releases. However, little is known about the current distribution of the endangered galaxiids, or the roles that natural and human-mediated dispersal may have played in the dispersal of brown trout following the initial introductions.

Here we reconstructed the introduction and establishment of brown trout in the Falkland Islands using historical records and modelled its dispersal using anthropogenic and bioclimatic variables. We also derived risk maps under different management scenarios to help conservation agencies identify galaxiid populations at high risk of invasion and prioritise the establishment of freshwater refugia. 


\section{Methods}

Reconstructing the introductions of brown trout

Historical records of the introduction of salmonids in the Falkland Islands (Table S1) were compiled and cross-referenced from (Arrowsmith and Pentelow 1965) and (Stewart 1973; Stewart 1980), supplemented with information from the media in the United Kingdom (Salmon and Trout 2012), and from (Basulto 2003), (Faundez et al. 1997) and (Daciuk 1975) in South America. We also searched the Stirling University library for shipment records from the Howietoun hatchery (built in 1881) as this had dispatched salmonid eggs across the world.

\section{Sampling of freshwater fish}

A database of presence/absence records of the four species of freshwater fish present in the Falklands (three native galaxiids, $A$. zebra, $A$. taeniatus, and $G$. maculatus; and the non-native brown trout) was compiled by cross-checking records from (McDowall et al. 2001; Ross 2009), expanded with information from angler reports and our own sampling (Fowler 2013). McDowall's (McDowall et al. 2001) fish survey employed seine, gill and fyke netting, spotlighting at night, and electrofishing of $\sim 50 \mathrm{~m}$ stream reaches. Ross (Ross 2009) employed electrofishing, seine netting and visual checks. We used single-pass electrofishing (Smith-Root ELBP2), seine netting and visual surveys during 2011-2013 to add 28 new sites to the database, bringing the total number of sites sampled for freshwater fish to 134 (Table S2).

\section{Species distribution modelling}

We divided the Falkland Islands into $8,8131 \times 1 \mathrm{~km}^{2}$ grid cells, and excluded cells that had more than $30 \%$ of their area in the sea and those that contained no rivers, as in a previous species distribution modelling (Rodriguez-Rey et al. 2019). Brown trout presence was modelled using 13 anthropogenic and 9 bioclimatic predictors (Table S3) for which we extracted mean values or took the value from the centre of the grid cell using QGIS 3.4. We excluded three predictors with VIF>3 to reduce collinearity, and randomly divided equal numbers of presence and absence records into training and testing datasets from 134 sites (Table S2) to train and test the model.

Brown trout distribution was modelled via a generalized linear model and the Leave One Out Cross Validation (LOOCV) (Hooten and Hobbs 2015). The drop1 function in R3.5.3 (R Core Team 2019) was used to test the significance of individual predictors and arrive at a minimal adequate model based on changes in AIC. Model performance was assessed using the under the curve (AUC) criterion and compared against a null model built using the same testing and training datasets used for the final model (Rodriguez-Rey et al. 2019) using parametric bootstrapping $(1,000$ simulations).

\section{Establishment success and calculation of invasion risk}

To calculate establishment success, we compared the proportion of introduction sites that still had brown trout $~ 50$ years later against the random $50 \%$ expectation using a binomial test. We then used presence/absence data for brown trout and the three native galaxiids to assess how the presence of brown trout influenced the presence of native galaxiids by calculating relative risks. To visualize invasion risk, we used QGIS 3.10.3 to generate invasion risk maps based on the probability of 
brown trout occurrence, calculated using the LOOCV procedure across all valid grid cells, as explained above.

Predictive modelling of brown trout invasions under different management scenarios We modelled the occupancy of brown trout since 1950 and predicted its future dispersal over a 130-year period ( 30 generations) considering three different management scenarios: (1) no containment, (2) moderate containment (a $10 \%$ reduction in the probability of invasion at each cell), and (3) strong containment (a $30 \%$ reduction in the probability of invasion at each cell). For cells with a high probability of invasion ( $p \geq 0.8$ ) we assumed that containment would not be effective so we maintained the original invasion probabilities (i.e. no containment, scenario 1).

As grid cells were found to be more likely to become invaded if they were close to invaded sites (see Results), we calculated the Euclidean distance from each uninvaded site to the nearest invaded site. Invasion probabilities were then updated at each iteration under the three scenarios outlined above. Each scenario was run over 300 iterations to obtain a mean percentage occupancy and $95 \%$ binomial confidence intervals. We used the observed rate of expansion $(0.9 \%$ increase in occupancy/yr since 1950) to calibrate the model and convert the number of model iterations into calendar years (one iteration $=\sim 24$ years or $\sim 4$ generations).

\section{Ethics \& Permits}

Fish sampling was carried out under permit number R18/2018 (17/04/2018) issued by the Falkland Islands Government (Falkland Islands Environmental Committee) and Swansea University Ethics Committee (Reference number SU-Ethics-Student081217/307; SU-Ethics-Student-090118/299; SU-Ethics-Student-160118/463. 


\section{Results}

Origin of brown trout

Approximately 113,000 brown trout eggs were shipped to the Falkland Islands on eight separate occasions over an 18-year period (1944-1962, Table S1). Although original records are missing, many consignments were described as arriving in 'excellent condition' (Stewart 1973). The first introductions (1944-1947) came from the Lautaro hatchery in Chile (Arrowsmith and Pentelow 1965; MacCrimmon and Marshall 1968), and were primarily sourced from resident (i.e. non-anadromous) parents of German origin (Faundez et al. 1997; Radcliffe 1922). Subsequent eggs came from three sources in England: Surrey, Pentlands and Lancashire. The Surrey and Pentlands fish were from resident parents, while the Lancashire trout were derived from 'sea run trout' caught in the River Lune (Arrowsmith and Pentelow 1965). The provenance of the Pentlands resident trout is unclear, but it may have originated from Cobbinshaw Loch (Arrowsmith and Pentelow 1965; Stewart 1973), Loch Leven (Fish Loch Leven 2019), or the Howietoun Hatchery (Ross Gardiner, pers. comm.). The Howietoun hatchery had reared trout from Loch Leven and many other sources, but we found no records of fish having ever been sent to the Falkland Islands. In total 28 different sites were stocked (Table S1), but three rivers - all within a $25 \mathrm{~km}$ radius of the capital Stanley - received most of the introductions.

\section{Establishment success}

Of the 17 stocked sites for which there are fish survey data, 15 sites still had brown trout 50 years later. Establishment success can therefore be estimated as $88 \%$ $(95 \mathrm{Cl}=62-98 \%)$, which is significantly better than chance $\left(\chi^{2}=8.47\right.$, df $=1, P=$ 0.004).

\section{Modelling of brown trout distribution}

At the time of the last survey (2012), brown trout occupied $54 \%$ of all sampled $1 \mathrm{~km}^{2}$ grid cells, with Aplochiton spp. only occupied 18\%, confined to the South of the Islands (Fig. 1). Brown trout occurrence was predicted by distance to the nearest invaded point in a straight line (estimate $=-0.238, \mathrm{SE}=0.067, t=-3.56, P<0.001$ ), absence of Aplochiton spp. (estimate $=-1.57, \mathrm{SE}=0.769, t=-2.04, P=0.041$ ) and number of river road crossings in the drainage basin (estimate $=0.156, \mathrm{SE}=0.066, t$ $=2.37, P=0.018$ ). The model explained the occurrence of brown trout significantly better than chance $(\mathrm{LRT}=52.17, \mathrm{df}=3, P<0.001, \mathrm{AUC}=0.85)$.

Impact of brown trout on native galaxiids

Native galaxiids were less likely to occur in streams invaded by brown trout than in uninvaded ones (Fig. 2), but the impact of invasive brown trout was more pronounced in the case of Aplochiton sp. Calculation of relative risk indicated that Aplochiton $s p$ was 4.5 times less likely to persist in streams invaded by brown trout than in uninvaded streams $(95 \mathrm{Cl}=1.8-11.2, P<0.001)$. For Galaxias maculatus, the presence of brown trout decreased the probability of occurrence 2.9 fold $(95 \mathrm{Cl}=2.0$ 4.2, $P<0.001)$.

\section{Invasion risk}

A risk map generated from the probability of occurrence of brown trout identified $21 \%$ of cells with a very high risk of invasion $(R \geq 0.75), 24 \%$ with a high risk $(R=0.50$ $0.75), 17 \%$ with moderate risk $(R=0.25-0.50)$ and $38 \%$ with low risk $(R<0.25)$. By 
overlaying the distribution of the endangered Aplochiton spp. we identified 9 sites at a high or very high risk of invasion where preventive measures should be prioritised to exclude brown trout and protect native freshwater fish (Fig. 3).

Invasion under different management scenarios

Our simulations indicate that if nothing is done (scenario 1) brown trout will likely increase its occupancy from $54 \%$ to $93 \%$ within the next 70 years $(95 \mathrm{Cl}=70-99 \%)$. Under scenario 2 (moderate containment) occupancy is predicted to increase to $86 \%$ $(95 \mathrm{Cl}=59-94 \%)$ and to $69 \%(95 \mathrm{Cl}=47-81 \%)$ with strong containment (scenario 3 , Fig. 4). Thus, occupancy is predicted to increase under all the three scenarios, but only with strong containment can current Aplochiton refugia be protected from trout invasions. 


\section{Discussion}

Our study indicates that brown trout have already invaded $54 \%$ of the streams in the Falkland Islands since they were introduced in 1944-1962, and are impacting on native freshwater fish. Streams invaded by brown trout were 2.9 times less likely to harbour Galaxias maculatus and 4.5 times less likely to contain Aplochiton sp. than uninvaded streams, suggesting the impacts are substantial. This finding is consistent with competitive exclusion of native galaxiids by invasive brown trout (Garcia de Leaniz et al. 2010; Young et al. 2009), exacerbated by predation and trophic interference (Arismendi et al. 2014; Elgueta et al. 2013). Our simulations suggest that unless more stringent measures are put in place, brown trout will likely invade nearly all the suitable freshwater habitats in the Falklands within the next $\sim 70$ years. Given that endangered Aplochiton sp. only occupy $\sim 18 \%$ of the area, mostly confined to southern part of the Islands, this could drive the species to extinction.

The establishment success of brown trout in the Falklands was very high (88\%), as seen elsewhere in the Southern Hemisphere (Arismendi et al. 2014; Young et al. 2010). For example, in Argentina no failed introduction of brown trout was ever reported (Baigún and Quirós 1985). Several factors may help explain this. Firstly, our study shows that brown trout introduced into the Falklands originated from at least four different origins with two life history strategies, which resulted in genetic admixture (Minett et al. 2021b). Multiple origins and genetic admixture can increase genetic diversity and facilitate adaptation to novel conditions (Consuegra et al. 2011), which along with repeated introductions may increase invasion success. Another reason for the success of brown trout in the Falklands may lie in their high phenotypic plasticity and facility for marine dispersal, which seems to have facilitated the colonization of coastal rivers in the Falklands, a point recently confirmed by acoustic tracking (Minett et al. 2021b).

However, marine dispersal alone cannot explain the current distribution of brown trout in the Islands; secondary translocations must have also taken place because the species is now found in land-locked sites, where it could not have reached without human intervention. Transporting brown trout has been illegal in the Falklands since 1999, but some translocations must have taken place (McDowall et al. 2001). Indeed, our results indicate that brown trout presence was predicted by proximity to other invaded sites (overland, but not around the coast) and by the density of river-road crossings, which is consistent with secondary translocations facilitated by the road network, as seen in many other aquatic invasive species. For example, roads facilitated the expansion of smallmouth bass (Micropterus dolomieu) in remote lakes in Canada (Kaufman et al. 2009) and of bluegill (Lepomis macrochirus) in Japan (Kizuka et al. 2014). The Falklands has $\sim 800 \mathrm{~km}$ of road tracks crisscrossing a dense river network, most of which have been built over the last three decades (Fowler and Garcia de Leaniz 2012), and it is likely that this may have facilitated the expansion of brown trout. Recent eDNA analysis of water samples (Minett et al. 2021a) has revealed the presence of brown trout in additional streams since our last survey, suggesting that the species is expanding at a rate of $\sim 0.9 \% /$ year.

Other invasive salmonids are also threatening the native fish fauna of the Falklands. For example, both chinook salmon (Oncorhynchus tshawytscha) and coho salmon 
(Oncorhynchus kisutch) are increasingly being caught off West Falkland (Fowler 2013), most likely originating from Chile or Argentina, highlighting the potential for further salmonid invasions. Similarly, the development of sea trout farming in opennet cages in the Falklands in 2013 poses a risk of escapees, which could further compromise the survival of native galaxiids, as seen in Patagonia (Consuegra et al. 2011; Vanhaecke et al. 2012), particularly if sea cages are located close to Aplochiton refugia. Given the widespread ecological damage caused by invasive salmonids, being able to identify areas at high risk of invasion is critical for managing and curtailing their expansion. In this sense, our risk maps allows conservation officers to identify high risk areas, and could be used as part of an integrated management strategy for managing invasive salmonids in the Falklands.

\section{Conclusions \& Recommendations}

Galaxiids rank among the most severely threatened fish in the world due to the introduction of invasive salmonids (Garcia de Leaniz et al. 2010; McDowall 2006). Our modelling suggests that without containment and strict measures brown trout will likely invade all remaining suitable water bodies in the Falklands before the end of the century, putting the endangered freshwater fish of the Islands at a high risk of extinction.

Existing legislation makes it illegal to transport or propagate brown trout in the Falklands, but this seems insufficient as the species is also afforded a protected status, and fishing for trout is widely promoted (Falkland Islands Government 2015), which may facilitate its spread. The road network appears to be a main route of human-assisted translocations, and is essential that more stringent measures are put in place. This may involve making people more aware of the impacts of salmonid invasions and passing more stringent legislation. Exclusion barriers could also be deployed around galaxiid refugia to reduce the risk of salmonid invasions (Jones et al. 2021b), but care must be taken to ensure this does not impact on native galaxiids, which may pose a challenge as even small barriers can have negative impacts on weak swimmers (Jones et al. 2021a). Brown trout is subject to a bag limit and a strict fishing season and it might be useful to consider lifting these restrictions in some places to slow down the invasion front. Intensive fishing could be used to eradicate brown trout and establish buffer zones around Aplochiton refugia; analysis of eDNA from water samples could be used to delineate such refugia (Minett et al. 2021a), to serve as an early warning of brown trout invasions, and to establish whether containment measures have been successful.

Since McDowall's call for action 20 years ago (McDowall et al. 2001), brown trout has continued to expand while native galaxiids have continued to decline. Aplochiton $\mathrm{sp}$. features in a postal stamp of the Islands while Galaxias maculatus is called 'Falklands minnow', testifying to their importance for local islanders, and their place in the natural and cultural heritage of the Islands. Salmonids have brought wealth and recreation opportunities to the Falklands, but have also caused the demise of native freshwater fish. Our study indicates that urgent protection measures are needed to safeguard their survival.

\section{Acknowledgements}


We thank William P. Kay for help calculating distance around the coast, Supercomputing Wales for use of the Sunbird cluster, and Falkland Islands Government IMS-GIS Centre and SAERI for providing GIS data. Funding from Fortuna Ltd. and Swansea University College of Science is gratefully acknowledged.

\section{References}

Arismendi I., Penaluna B.E., Dunham J.B. et al. (2014) Differential invasion success of salmonids in southern Chile: patterns and hypotheses. Reviews in Fish Biology and Fisheries 24, 919-941.

Arrowsmith E., Pentelow F.T.K. (1965) The introduction of trout and salmon to the Falkland Islands. pp. 119-129. Salmon and Trout Magazine.

Baigún C.R.M., Quirós R. (1985) Introducción de peces exóticos en la República Argentina. p. 93. Informes Técnicos del Departamento de Aguas Continentales. Instituto Nacional de Investigación y Desarrollo Pequero, Mar del Plata, Argentina. Basulto S. (2003) El largo viaje de los salmones: una crónica olvidada. Propagación y cultivo de especies acuáticas en Chile. . Maval Limitada Editores, Santiago, Chile. Consuegra S., Phillips N., Gajardo G., Garcia de Leaniz C. (2011) Winning the invasion roulette: Escapes from fish farms increase admixture and facilitate establishment of non-native rainbow trout. Evolutionary Applications 4, 660-671. Daciuk J. (1975) La fauna silvestre de las Islas Malvinas. Anales de la Sociedad Científica Argentina 199, 152-176.

Elgueta A., González J., Ruzzante D.E., Walde S.J., Habit E. (2013) Trophic interference by Salmo trutta on Aplochiton zebra and Aplochiton taeniatus in southern Patagonian lakes. Journal of Fish Biology 82, 430-443.

Ewel J.J., Högberg P. (1995) Experimental studies on islands. Springer Berlin Heidelberg.

Falkland Islands Government. (2015) Trout fishing in the Falkland Islands. Faundez V., Blanco G., Vázquez E., Sánchez J.A. (1997) Allozyme variability in brown trout Salmo trutta in Chile. Freshwater Biology 37, 507-514.

Fish Loch Leven. (2019) History of Loch Leven.

Fowler D., Garcia de Leaniz C. (2012) Assessing the impact of culverts on population connectivity of endangered galaxiid fishes in the Falkland Islands. pp. 5859 in P. Gough, P. Philipsen, P.P. Schollema, H. Wanningen editors. From Sea to Source International Guidance for the Restoration of Fish Migration Highways Regional Water Authority Hunze en Aa's Postbus 195, 9640 AD Veendam, The Netherlands.

Fowler D.M. (2013) Brown trout in the Falklands: origin, life history, and public attitudes to an invasive species. pp. 1-110.

Garcia de Leaniz C., Gajardo G., Consuegra S. (2010) From Best to Pest: changing perspectives on the impact of exotic salmonids in the southern hemisphere.

Systematics and Biodiversity 8, 447-459.

Hooten M.B., Hobbs N.T. (2015) A guide to Bayesian model selection for ecologists. Concepts and synthesis 85, 3-28.

Hulme P.E. (2015) Invasion pathways at a crossroad: Policy and research challenges for managing alien species introductions. Journal of Applied Ecology 52, 1418-1424.

Jones P., Champneys T., Vevers J. et al. (2021a) Selective effects of small barriers on river-resident fish. Journal of Applied Ecology. 
Jones P.E., Tummers J.S., Galib S.M. et al. (2021b) The use of barriers to limit the spread of aquatic invasive animal species: a global review. Frontiers in Ecology and Evolution.

Kaufman S.D., Snucins E., Gunn J.M., Selinger W. (2009) Impacts of road access on lake trout (Salvelinus namaycush) populations: Regional scale effects of overexploitation and the introduction of smallmouth bass (Micropterus dolomieu). Canadian Journal of Fisheries and Aquatic Sciences 66, 212-223.

Kizuka T., Akasaka M., Kadoya T., Takamura N. (2014) Visibility from roads predict the distribution of invasive fishes in agricultural ponds. PLOS ONE 9.

Lowe S., Browne M., Boudjelas S., De Poorter M. (2000) 100 of the World's Worst Invasive Alien Species A selection from the Global Invasive Species Database p. 12. Invasive Species Specialist Group (ISSG), World Conservation Union (IUCN) MacCrimmon H.R., Marshall T.L. (1968) World distribution of brown trout Salmo trutta. J Fish Res Board Can 25, 2527-2548.

McDowall R.M. (2003) Impacts of introduced salmonids on native galaxiids in New Zealand upland streams: a new look at an old problem. Transactions of the American Fisheries Society 132, 229-238.

McDowall R.M. (2006) Crying wolf, crying foul, or crying shame: alien salmonids and a biodiversity crisis in the southern cool-temperate galaxioid fishes? Reviews in Fish Biology and Fisheries 16, 233-422.

McDowall R.M., Allibone R.M., Chadderton W.L. (2001) Issues for the conservation and management of Falkland Islands fresh water fishes. Aquatic Conservation: Marine and Freshwater Ecosystems 11, 473-486.

Minett J.F., Garcia de Leaniz C., Brickle P., Consuegra S. (2021a) A new highresolution melt curve eDNA assay to monitor the simultaneous presence of invasive brown trout (Salmo trutta) and endangered galaxiids. Environmental DNA 3, 561572.

Minett J.F., Garcia de Leaniz C., Sobolewska H., Brickle P., Crossin G.T., Consuegra S. (2021b) SNP analysis and acoustic tagging reveal multiple origins and widespread dispersal of invasive brown trout in the Falkland Islands Evolutionary Applications.

Radcliffe L. (1922) Fisheries and market for fishery products in Mexico, Central America, South America, West Indies, and Bermudas. Office UGP, Washington. Rodriguez-Rey M., Consuegra S., Borger L., Garcia de Leaniz C. (2019) Improving Species Distribution Modelling of freshwater invasive species for management applications. PLoS One 14, e0217896.

Ross K. (2009) Freshwater fish in the Falklands: conservation of native zebra trout. A report to the Falkland Islands Government and Falklands Conservation.

Salmon, Trout A. (2012) Falklands in the Family.

Stewart L. (1973) Fisheries of the Falkland Islands.

Stewart L. (1980) A history of migratory salmon acclimatization experiments in parts of the southern hemisphere and the possible effects of oceanic currents and gyres upon their outcome. Adv Mar Biol 17, 397-466.

Tabak M.A., Piaggio A.J., Miller R.S., Sweitzer R.A., Ernest H.B. (2017) Anthropogenic factors predict movement of an invasive species. Ecosphere 8. Vanhaecke D., Garcia de Leaniz C., Gajardo G., Thomas C., Consuegra S. (2012) Metapopulation dynamics of a diadromous galaxiid fish and potential effects of salmonid aquaculture. Freshwater Biology 57, 1241-1252.

Young K., Dunham J., Stephenson J. et al. (2010) A trial of two trouts: comparing the impacts of rainbow and brown trout on a native galaxiid. Animal Conservation, 1-10. 
bioRxiv preprint doi: https://doi.org/10.1101/2021.06.15.448501; this version posted June 16, 2021. The copyright holder for this preprint

(which was not certified by peer review) is the author/funder, who has granted bioRxiv a license to display the preprint in perpetuity. It is made available under aCC-BY-NC-ND 4.0 International license.

Young K.A., Stephenson J., Terreau A., Thailly A.-F., Gajardo G., Garcia de Leaniz C. (2009) The diversity of juvenile salmonids does not affect their competitive impact on a native galaxiid. Biological Invasions 11, 1955-1961. 


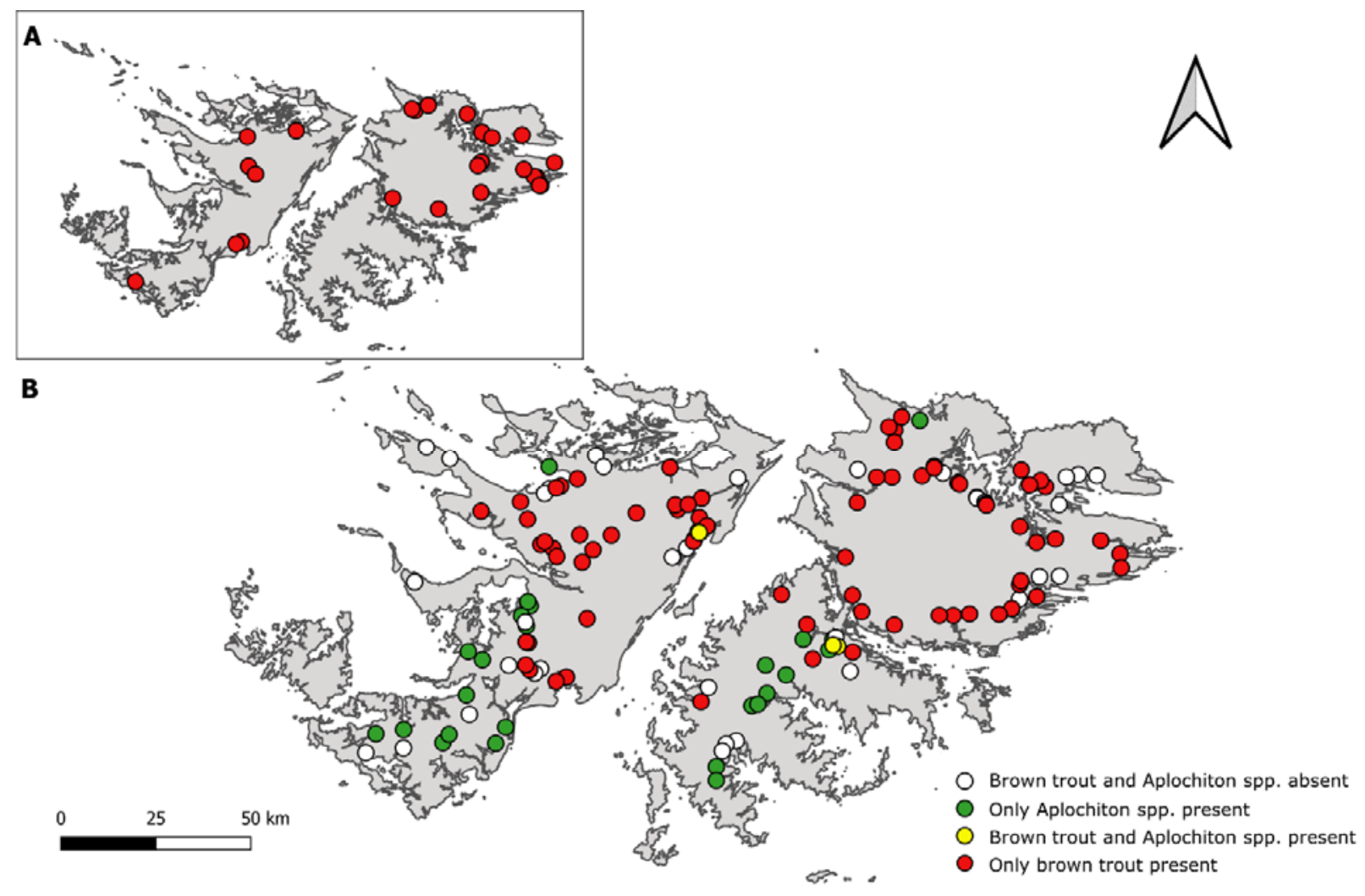

Figure 1. Map of the Falkland Islands showing (A) sites of the historical introductions of brown trout during 1944-1962 (details given in Table S1) and (B) presence/absence of brown trout and native Aplochiton sp. based on 1999-2012 surveys (detailed in Table S2) with 6 additional sites sampled in 2018-2019. 


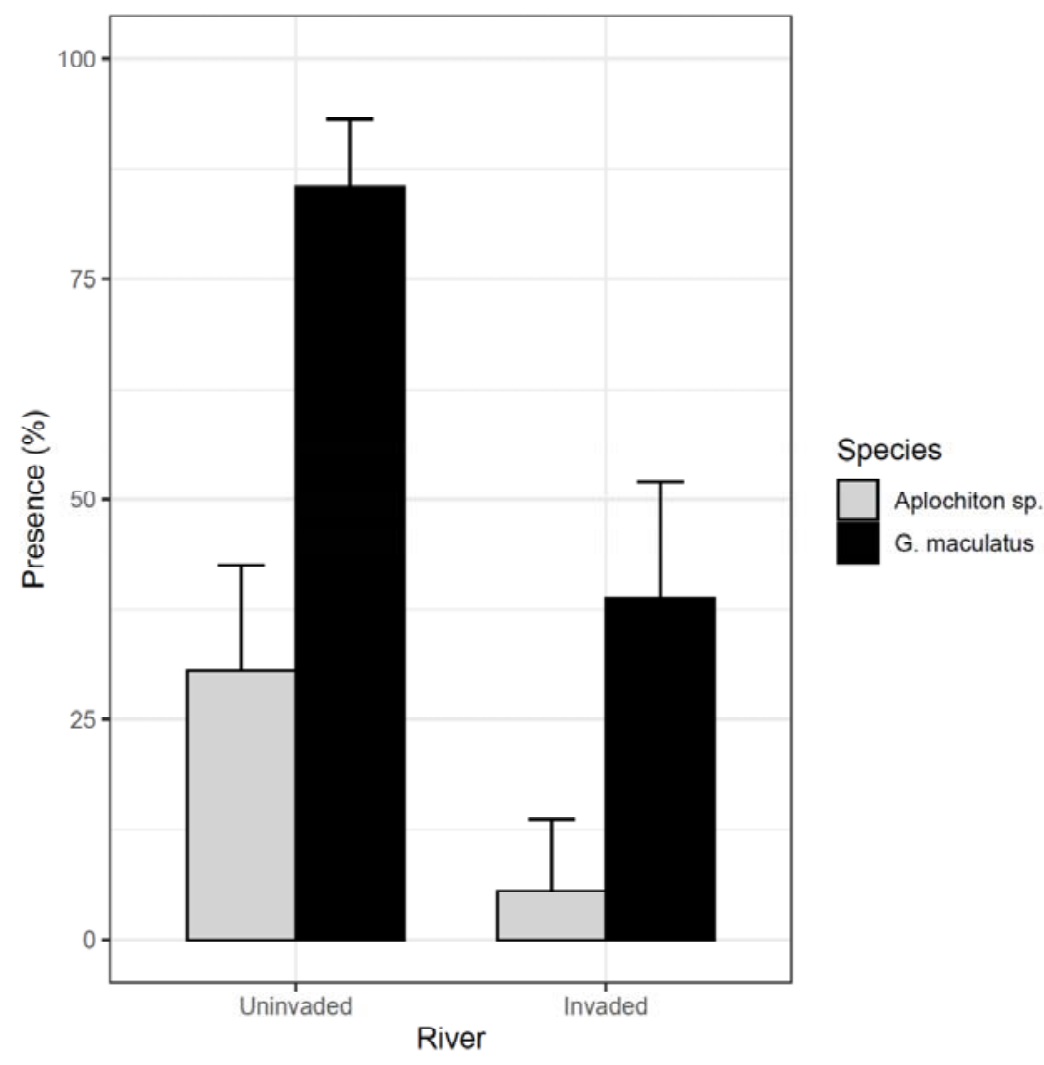

Figure 2. Frequency of occurrence (\% and binomial upper $95 \mathrm{Cl})$ of native galaxiids (Galaxias maculatus and Aplochiton sp.) in streams invaded by brown trout $(\mathrm{N}=62)$ and in uninvaded streams $(\mathrm{N}=72)$. 


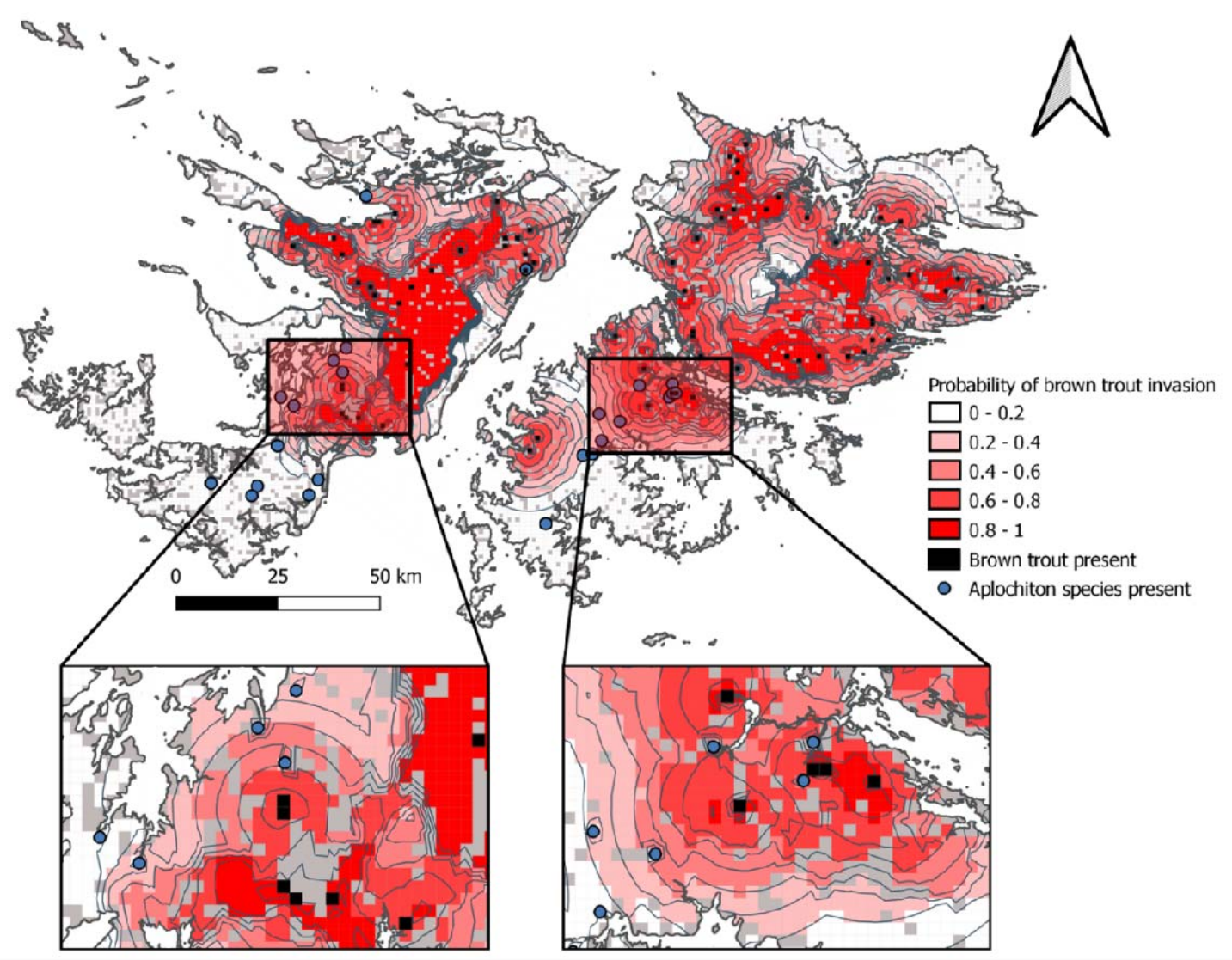

Figure 3. Risk maps showing probabilities of brown trout invasion based on species distribution modelling. Aplochiton refugia at a high risk of brown trout invasion are shown in the zoomed insets. 


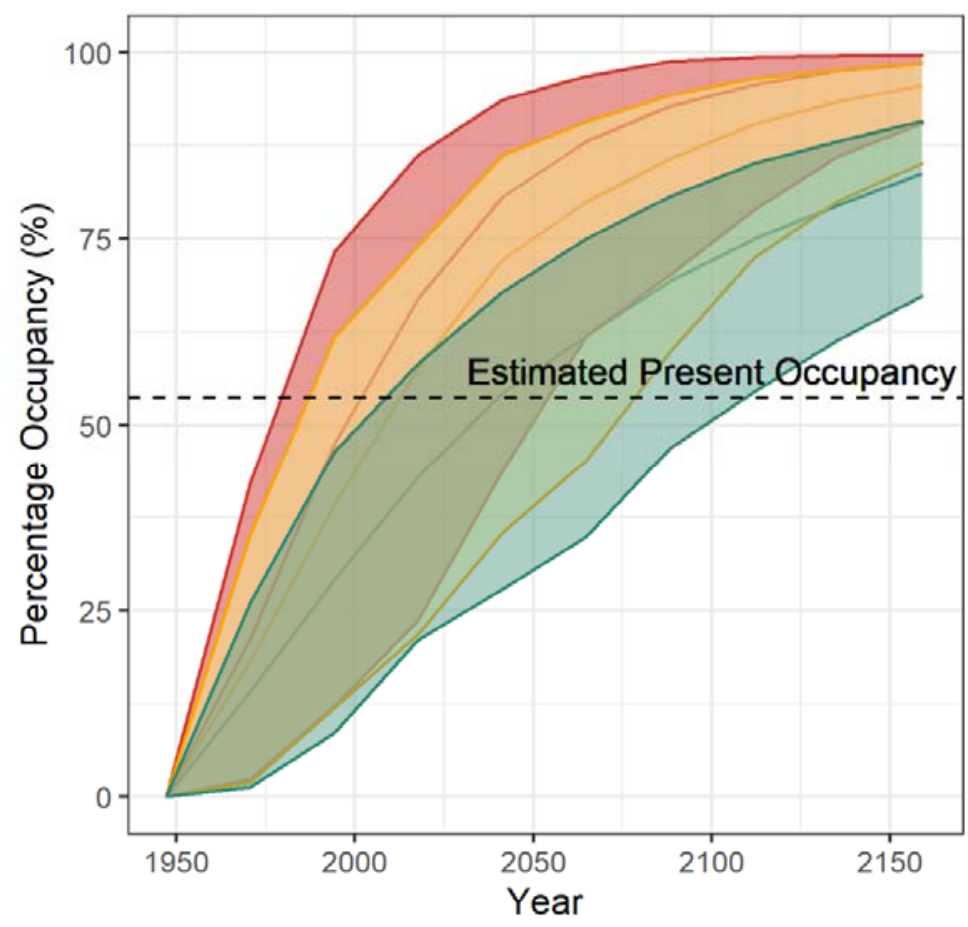

No containment

Moderate containment

Strong containment

Figure 4. Modelled expansion of brown trout in the Falkland Islands under three different management scenarios. 
Table S1. Introduction of brown trout eggs in the Falkland Islands, 1944-1962.

\begin{tabular}{|c|c|c|c|c|c|}
\hline Stock origin & Year & Quantity & Introduction Site (code) & Latitude & Longitude \\
\hline \multicolumn{6}{|c|}{ Unknown (likely Germany via Chile; non-anadromous) } \\
\hline & \multirow{3}{*}{1944} & \multirow[t]{3}{*}{ 'Small quantities' } & Unknown & Unknown & Unknown \\
\hline & & & Moody Brook & -51.6857 & -57.9222 \\
\hline & & & Moody Brook & -51.6857 & -57.9222 \\
\hline \multicolumn{6}{|c|}{ Lautaro Hatchery (Chile, German Stock; non-anadromous) } \\
\hline & \multirow[t]{3}{*}{1947} & \multirow[t]{3}{*}{30,000} & Moody Brook & -51.6857 & -57.9222 \\
\hline & & & Malo River & -51.6171 & -58.3018 \\
\hline & & & Murrell River & -51.6535 & -57.9951 \\
\hline \multicolumn{6}{|c|}{ Surrey Trout Farm (UK; non-anadromous) } \\
\hline & \multirow[t]{5}{*}{1948} & \multirow[t]{6}{*}{10,000} & Malo River & -51.6171 & -58.3018 \\
\hline & & & Murrell River & -51.6535 & -57.9951 \\
\hline & & & Hill Cove & -51.4736 & -59.9764 \\
\hline & & & Chartres River & -51.6428 & -59.9283 \\
\hline & & & Port Howard/Warrah R. & -51.4554 & -59.6245 \\
\hline \multicolumn{5}{|c|}{ Surrey Trout Farm or Pentlands (UK; non-anadromous) } & \\
\hline & \multirow[t]{12}{*}{1949} & \multirow{12}{*}{15,000} & Port San Carlos & -51.5095 & -58.8220 \\
\hline & & & Elephant Beach & -51.3807 & -58.7690 \\
\hline & & & Head of the Bay & -51.6061 & -59.0142 \\
\hline & & & Lorenzo Pond & -51.3497 & -59.6700 \\
\hline & & & Swan Inlet & -51.8239 & -58.6161 \\
\hline & & & Fitzroy River & -51.7546 & -58.3068 \\
\hline & & & Kidney Pond & -51.6251 & -57.7739 \\
\hline & & & Pebbly Pond & -51.7270 & -57.8740 \\
\hline & & & Johnsons Harbour & -51.4995 & -58.0044 \\
\hline & & & Fox Bay East & -51.9421 & -60.0500 \\
\hline & & & Fox Bay West & -51.9510 & -60.0897 \\
\hline & & & Hill Cove & -51.4736 & -59.9764 \\
\hline \multicolumn{6}{|c|}{ Surrey Trout Farm or Pentlands (UK; non-anadromous) } \\
\hline & \multirow{9}{*}{1950} & \multirow{9}{*}{10,000} & Darwin (Camilla Creek) & -51.7711 & -58.9457 \\
\hline & & & Malo River & -51.6171 & -58.3018 \\
\hline & & & Port San Carlos & -51.5095 & -58.8220 \\
\hline & & & Fitzroy River & -51.7546 & -58.3068 \\
\hline & & & Pebble Island & -51.3199 & -59.5741 \\
\hline & & & Chartres River & -51.6428 & -59.9283 \\
\hline & & & Hill Cove & -51.4736 & -59.9764 \\
\hline & & & Port Howard/Warrah River & -51.4554 & -59.6245 \\
\hline & & & Port Stephens & -52.0980 & -60.8321 \\
\hline \multicolumn{6}{|c|}{ Surrey Trout Farm or Pentlands (UK; non-anadromous) } \\
\hline & \multirow[t]{6}{*}{1951} & 10,000 & Malo River & -51.6171 & -58.3018 \\
\hline & & & Swan Inlet & -51.8239 & -58.6161 \\
\hline & & & Darwin (Camilla Creek) & -51.7711 & -58.9457 \\
\hline & & & North Arm & -52.1291 & -59.3709 \\
\hline & & & Port San Carlos & -51.5095 & -58.8220 \\
\hline & & & Murrell River & -51.6535 & -57.9951 \\
\hline Surrey Trout & arm or & ntlands (UK; non-a & adromous) & & \\
\hline & 1952 & 10,000 & Murrell River & -51.6535 & -57.9951 \\
\hline & & & Malo River & -51.6171 & -58.3018 \\
\hline & & & Johns Brook & -51.4865 & -58.2932 \\
\hline & & & Lorenzo Pond & -51.3497 & -59.6700 \\
\hline & & & Fitzroy River & -51.7546 & -58.3068 \\
\hline & & & Swan Inlet & -51.8239 & -58.6161 \\
\hline & & & North Arm & -52.1291 & -59.3709 \\
\hline & & & Pebbly Pond & -51.7270 & -57.8740 \\
\hline & & & Kidney Pond & -51.6251 & -57.7739 \\
\hline Middleton $\mathrm{Ha}$ & hery & ncashire Fisheries & oard (UK; anadromous) & & \\
\hline & 1961 & 20,000 & Chartres River & -51.6428 & -59.9283 \\
\hline & & & Mac's Paddock Brook & -51.4849 & -58.2927 \\
\hline
\end{tabular}


bioRxiv preprint doi: https://doi.org/10.1101/2021.06.15.448501; this version posted June 16, 2021. The copyright holder for this preprint (which was not certified by peer review) is the author/funder, who has granted bioRxiv a license to display the preprint in perpetuity. It is made available under aCC-BY-NC-ND 4.0 International license.

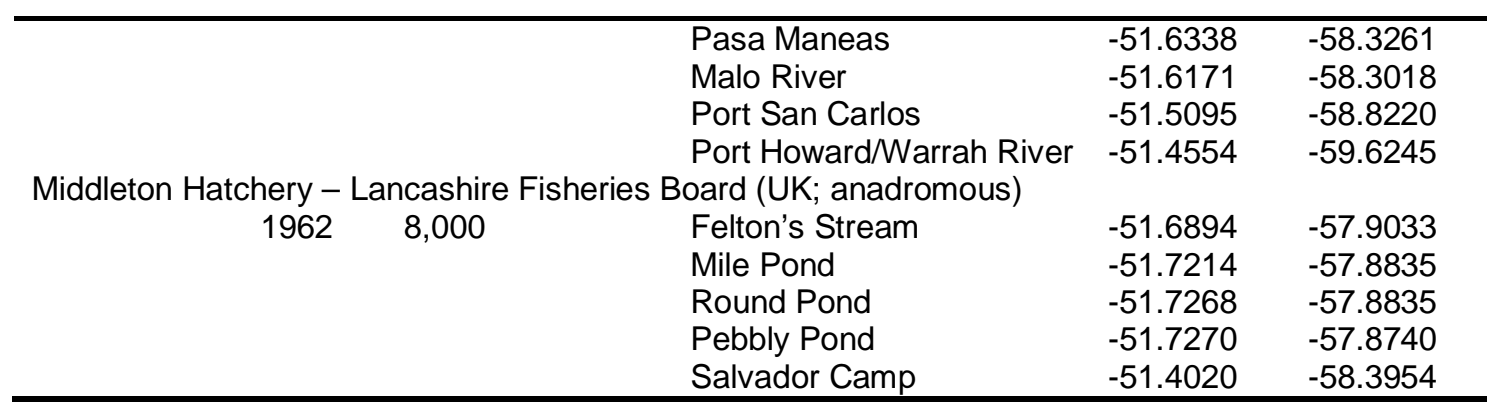


Table S2. Presence/absence of brown trout (St), Aplochiton sp. (Ap) and Galaxias maculatus (Gm) in the Falkland Islands. Sites marked with an asterisk denote brown trout introduction sites (see Table S1).

\begin{tabular}{|c|c|c|c|c|c|c|c|c|}
\hline Sample Site & Island & $\begin{array}{l}\text { Date last } \\
\text { sampled }\end{array}$ & Lat. & Long. & $S t$ & $A p$ & $\mathrm{Gm}$ & Reference \\
\hline Arrow Harbour Arroyo & East & 2011 & -51.9062 & -58.9508 & + & - & + & Fowler (2013) \\
\hline Arroyo Pedro & East & 1999 & -51.5111 & -58.5346 & + & - & - & McDowall et al. (2001) \\
\hline Big Pond & East & 2018 & -51.8433 & -51.7522 & + & - & + & Minett (unpubl.) \\
\hline Bodie Creek & East & 2011 & -51.9191 & -59.1042 & + & - & + & Fowler (2013) \\
\hline Bull Pass Stream & East & 2011 & -51.8909 & -59.0074 & + & + & + & Fowler (2013) \\
\hline Clay Ditch & East & 1999 & -51.4925 & -58.6700 & + & - & - & McDowall et al. (2001) \\
\hline Colorado Pond & East & 2018 & -51.7136 & -58.4717 & + & - & - & Minett (unpubl.) \\
\hline Comoda Ditch & East & 1999 & -51.8219 & -58.5003 & + & - & - & McDowall et al. (2001) \\
\hline Congo Ponds Area & East & 2009 & -51.9787 & -59.5072 & - & - & - & Ross (2009) \\
\hline Dan's Shanty Stream & East & 1999 & -51.5236 & -58.2020 & + & - & + & McDowall et al. (2001) \\
\hline Darwin (Camilla Creek) * & East & 1999 & -51.7711 & -58.9457 & + & - & - & McDowall et al. (2001) \\
\hline Deep Arroyo & East & 2011 & -51.9553 & -59.2080 & - & + & + & Fowler (2013) \\
\hline Ditches into New Haven & East & 2009 & -51.7646 & -59.2166 & + & - & + & Ross (2009) \\
\hline Duffins Bridge Stream & East & 2009 & -52.1078 & -59.4073 & - & - & + & Ross (2009) \\
\hline Elephant Beach Pond* & East & 1999 & -51.3807 & -58.7690 & + & - & + & McDowall et al. (2001) \\
\hline Elmer's Ditch Tributary & East & 1999 & -51.4939 & -58.7840 & + & - & - & McDowall et al. (2001) \\
\hline Estancia Brook & East & 2008 & -51.6480 & -58.1678 & + & - & - & Fowler (2013) \\
\hline Felton Stream* & East & NA & -51.6894 & -57.9033 & NA & NA & NA & Not sampled \\
\hline Findley Creek Stream & East & 2011 & -51.8882 & -59.0250 & + & + & + & Fowler (2013) \\
\hline $\begin{array}{l}\text { Findlay Harbour } \quad \text { (Wreck } \\
\text { House) }\end{array}$ & East & 2009 & -52.0122 & -59.5375 & + & - & - & Fowler (2013) \\
\hline Fitzroy River* & East & 2012 & -51.7546 & -58.3068 & + & NA & NA & Angler \\
\hline Frying Pan & East & 2011 & -51.8111 & -58.3387 & + & - & - & Fowler (2013) \\
\hline Gonzales Arroyo & East & 2009 & -51.9513 & -58.9621 & - & - & + & Ross (2009) \\
\hline Green Pass Brook Tributary & East & 1999 & -51.4098 & -58.7715 & + & - & - & McDowall et al. (2001) \\
\hline Head of the Bay ${ }^{\star}$ & East & 2012 & -51.6061 & -59.9764 & + & NA & NA & Angler \\
\hline Head of the Creek Stream & East & 1999 & -51.4961 & -58.0763 & - & - & + & McDowall et al. (2001) \\
\hline
\end{tabular}




\begin{tabular}{|c|c|c|c|c|c|c|c|c|}
\hline Hunter's Arroyo & East & 1999 & -52.1147 & -59.4470 & - & - & + & McDowall et al. (2001) \\
\hline Sample Site & Island & $\begin{array}{l}\text { Date last } \\
\text { sampled }\end{array}$ & Lat. & Long. & $S t$ & $\overline{A p}$ & $\mathrm{Gm}$ & Reference \\
\hline John's Brook* & East & 2018 & -51.4834 & -58.2930 & + & - & $\mathrm{NA}$ & Minett (unpubl.) \\
\hline Johnsons Harbour* & East & NA & -51.4995 & -58.0044 & NA & NA & NA & Not sampled \\
\hline Kidney Pond* & East & NA & -51.6251 & -57.7739 & NA & NA & NA & Not sampled \\
\hline Laguna Isla & East & 2011 & -51.8439 & -58.7890 & + & - & - & Fowler (2013) \\
\hline L'Antioja Stream & East & 2012 & -51.8249 & -58.5627 & + & - & - & Fowler (2013) \\
\hline Little Creek Stream & East & 1999 & -51.3504 & -58.7418 & + & - & - & McDowall et al. (2001) \\
\hline Lorenzo Pond* & East & 1973 & -51.3593 & -58.6730 & - & + & + & Stewart (1973) \\
\hline Mac's Paddock Brook* & East & NA & -51.4849 & -58.2927 & NA & NA & NA & Not sampled \\
\hline Magellan Pond & East & 1999 & -51.4995 & -58.0062 & - & - & + & McDowall et al. (2001) \\
\hline Malo River* & East & 1999 & -51.6171 & -58.3018 & + & - & + & McDowall et al. (2001) \\
\hline Mary Hill Quarry & East & 2018 & -51.6844 & -57.7894 & + & - & - & Minett (unpubl.) \\
\hline Mile Pond* & East & NA & -51.7214 & -57.8835 & NA & NA & NA & Not sampled \\
\hline Moody Brook* & East & 2012 & -51.6857 & -57.9222 & + & - & - & Fowler (2013) \\
\hline Mullet Creek & East & 1999 & -51.7187 & -57.9185 & + & - & + & McDowall et al. (2001) \\
\hline Murrell River* & East & 2013 & -51.6535 & -57.9951 & + & - & - & Fowler (2013) \\
\hline North Arm* & East & 2011 & -52.1291 & -29.3709 & - & - & + & Fowler (2013) \\
\hline Northwest Arm House Stream & East & 2018 & -52.1674 & -59.4874 & - & + & + & Minett (unpubl.) \\
\hline Northern Stream & East & 1999 & -51.5018 & -58.1223 & - & - & + & McDowall et al. (2001) \\
\hline Orequta Arroyo & East & 2011 & -51.8373 & -59.1229 & + & - & - & Fowler (2013) \\
\hline Pasa Maneas* & East & NA & -51.6338 & -58.3261 & NA & NA & NA & Not sampled \\
\hline Pebbly Pond* & East & NA & -51.7270 & -57.8740 & NA & NA & NA & Not sampled \\
\hline Round Pond* & East & NA & -51.7268 & -57.8835 & NA & NA & NA & Not sampled \\
\hline Rumford Brook & East & 2011 & -51.6557 & -58.2399 & + & - & - & Fowler (2013) \\
\hline Salvador Camp* & East & NA & -51.4020 & -58.3954 & NA & NA & NA & Not sampled \\
\hline San Carlos River at Ford* & East & 2018 & -51.5095 & -58.220 & + & - & - & Minett (unpubl.) \\
\hline Shepherds Brook & East & 1999 & -51.6808 & -58.9688 & + & . & + & McDowall et al. (2001) \\
\hline Spots Arroyo & East & 2018 & -52.0260 & -59.3432 & - & + & + & Minett (unpubl.) \\
\hline
\end{tabular}




\begin{tabular}{|c|c|c|c|c|c|c|c|c|}
\hline $\begin{array}{l}\text { Stream at Colorado Pass } \\
\text { Table S2 (cont). }\end{array}$ & East & 2009 & -51.8702 & -59.0137 & - & - & + & Ross (2009) \\
\hline Sample Site & Island & $\begin{array}{l}\text { Date last } \\
\text { sampled }\end{array}$ & Lat. & Long. & $S t$ & $A p$ & $G m$ & Reference \\
\hline Stream at Gibraltar Gate & East & 1999 & -51.4933 & -58.8417 & + & - & - & McDowall et al. (2001) \\
\hline Stream near Hunter Arroyo & East & 1999 & -52.1303 & -59.4622 & - & - & + & McDowall et al. (2001) \\
\hline Stream, Caneja Creek & East & 1999 & -51.5190 & -58.2621 & + & - & - & McDowall et al. (2001) \\
\hline Stream, at Fitzroy & East & 1999 & -51.7838 & -58.2425 & + & - & + & McDowall et al. (2001) \\
\hline Stream, Douglas Creek & East & 1999 & -51.4704 & -58.6229 & + & - & - & McDowall et al. (2001) \\
\hline Stream, Elephant Beach Pond* & East & 2018 & -51.3731 & -58.7911 & + & - & + & Minett (unpubl.) \\
\hline Stream, Fitzroy & East & 1999 & -51.7887 & -58.3085 & - & - & - & McDowall et al. (2001) \\
\hline Stream, Monty Dean's Creek & East & 1999 & -51.5669 & -58.1515 & - & - & + & McDowall et al. (2001) \\
\hline Stream, Mount Pleasant & East & 1999 & -51.8243 & -58.3878 & + & - & - & McDowall et al. (2001) \\
\hline Stream, NW of Teal Inlet & East & 1999 & -51.5456 & -58.4638 & - & - & + & McDowall et al. (2001) \\
\hline Stream NW of Teal Inlet & East & 1999 & -51.5481 & -58.4629 & - & - & + & McDowall et al. (2001) \\
\hline Stream, Salt House Creek & East & 2009 & -52.1997 & -59.4894 & - & + & + & Ross (2009) \\
\hline Stream, SE of Teal Inlet & East & 1999 & -51.5580 & -58.4330 & - & - & - & McDowall et al. (2001) \\
\hline Stream, Smylie's Brook & East & 1999 & -51.4738 & -58.9129 & - & - & - & McDowall et al. (2001) \\
\hline Stream, Teal Inlet & East & 1999 & -51.5654 & -58.4278 & + & - & - & McDowall et al. (2001) \\
\hline Stream, SE of Teal Inlet & East & 1999 & -51.5622 & -58.4294 & - & - & + & McDowall et al. (2001) \\
\hline Swan Inlet* & East & 2012 & -51.8239 & -58.6161 & + & NA & NA & Angler \\
\hline Teal Creek Arroyo & East & 2009 & -51.8106 & -58.9121 & + & - & + & Ross (2009) \\
\hline Third Corral Brook & East & 1999 & -51.5520 & -58.9182 & + & - & - & McDowall et al. (2001)) \\
\hline Trib., Halfway House Arroyo & East & 2011 & -51.9977 & -59.2836 & - & + & + & Fowler (2013) \\
\hline Turners Stream & East & 1999 & -51.5137 & -58.5277 & + & - & - & McDowall et al. (2001) \\
\hline Unnamed Stream & East & 1999 & -51.8726 & -59.1386 & - & + & + & McDowall et al. (2001) \\
\hline Unnamed Stream & East & 1999 & -51.9311 & -59.2855 & - & + & + & McDowall et al. (2001) \\
\hline Unnamed Stream & East & 1999 & -51.4869 & -58.5905 & - & - & - & McDowall et al. (2001) \\
\hline Unnamed Stream & East & 1999 & -52.0228 & -59.3197 & - & + & + & McDowall et al. (2001) \\
\hline Unnamed Stream & East & 1999 & -51.8987 & -59.0414 & - & + & + & McDowall et al. (2001) \\
\hline Unnamed Stream & East & 1999 & -51.8753 & -59.0254 & - & + & + & McDowall et al. (2001) \\
\hline
\end{tabular}




\begin{tabular}{|c|c|c|c|c|c|c|c|c|}
\hline $\begin{array}{l}\text { Unnamed Stream } \\
\text { Table S2 (cont). }\end{array}$ & East & 1999 & -51.7461 & -58.3020 & + & - & - & McDowall et al. (2001) \\
\hline Sample Site & Island & $\begin{array}{l}\text { Date last } \\
\text { sampled }\end{array}$ & Lat. & Long. & $S t$ & $A p$ & $\mathrm{Gm}$ & Reference \\
\hline Unnamed Stream & East & 1999 & -51.7366 & -58.2306 & - & - & + & McDowall et al. (2001) \\
\hline Unnamed Stream & East & 1999 & -51.7357 & -58.1542 & - & - & - & McDowall et al. (2001) \\
\hline Unnamed Stream & East & 1999 & -51.4747 & -58.6230 & + & - & - & McDowall et al. (2001) \\
\hline Pebble Island* & Pebble & NA & -51.3199 & $-59-5741$ & NA & NA & NA & Not sampled \\
\hline $1^{\text {st }}$ Arroyo & West & 2009 & -52.0838 & -60.5346 & - & + & - & Ross (2009) \\
\hline $2^{\text {nd }}$ Pass Stream & West & 1999 & -51.6253 & -60.1260 & + & - & - & McDowall et al. (2001) \\
\hline $2^{\text {nd }}$ Arroyo & West & 2009 & -52.0647 & -60.5092 & - & + & + & Ross (2009) \\
\hline Arroyo Chico & West & 1999 & -51.9208 & -60.1891 & + & - & - & McDowall et al. (2001) \\
\hline Arroyo Malo & West & 1999 & -51.9194 & -60.1471 & - & - & - & McDowall et al. (2001) \\
\hline Ballan Stream & West & 2009 & -51.6471 & -59.5714 & - & . & + & Ross (2009) \\
\hline Beach Stream & West & 1999 & -51.6258 & -59.5402 & + & - & + & McDowall et al. (2001) \\
\hline Bull Hill Stream & West & 1999 & -51.5764 & -59.5194 & + & - & - & McDowall et al. (2001) \\
\hline Bull Stream & West & 1999 & -51.4888 & -60.0413 & + & - & - & McDowall et al. (2001) \\
\hline Campbell Creek Stream & West & 2009 & -52.0197 & -60.4278 & - & - & + & Ross (2009) \\
\hline Cemetery Creek Estuary & West & 1999 & -51.5961 & -59.4913 & + & - & + & McDowall et al. (2001) \\
\hline Chartres River* & West & 1999 & -51.6428 & -59.9283 & + & - & - & McDowall et al. (2001) \\
\hline Daddy's Ditch & West & 2009 & -51.4195 & -59.9033 & - & - & + & Ross (2009) \\
\hline Dean's River & West & 2009 & -52.0914 & -60.6869 & - & - & + & Ross (2009) \\
\hline Dirty Ditch at the High Tide & West & 1999 & -51.5401 & -60.3470 & + & - & + & McDowall et al. (2001) \\
\hline Double Stream & West & 2009 & -51.6677 & -59.6277 & - & . & + & Ross (2009) \\
\hline Doyle River Tributary & West & 1999 & -51.7695 & -60.1764 & - & + & + & McDowall et al. (2001) \\
\hline Dunbar Creek & West & 2009 & -51.4124 & -60.4556 & - & - & + & Ross (2009) \\
\hline Edye Creek & West & 2012 & -51.8711 & -60.4206 & - & + & + & Fowler (2013) \\
\hline Fish Creek 1 & West & 2012 & -52.0538 & -60.2908 & - & + & + & Fowler (2013) \\
\hline Fish Creek 2 & West & 2018 & -51.8918 & -60.3681 & - & + & + & Minett (unpubl.) \\
\hline Fox Bay East* (Doctors Creek) & West & 2018 & -51.9421 & -60.0500 & + & - & NA & Minett (unpubl.) \\
\hline Fox Bay West* & West & 2012 & -51.9510 & -60.0897 & + & NA & NA & Angler \\
\hline
\end{tabular}




\begin{tabular}{|c|c|c|c|c|c|c|c|c|}
\hline $\begin{array}{l}\text { Gibraltar Stream } \\
\text { Table S2 (cont). }\end{array}$ & West & 2009 & -52.0913 & -60.3318 & - & + & + & Ross (2009) \\
\hline Sample Site & Island & $\begin{array}{l}\text { Date last } \\
\text { sampled }\end{array}$ & Lat. & Long. & $S t$ & $A p$ & $G m$ & Reference \\
\hline Green Hill Stream & West & 2009 & -51.5552 & -59.6012 & + & - & - & Ross (2009) \\
\hline Herbert Stream & West & 1999 & -51.5222 & -60.1959 & + & - & - & McDowall et al. (2001) \\
\hline Hawk's Nest Stream & West & 1999 & -51.8055 & -59.9614 & + & - & - & McDowall et al. (2001) \\
\hline Hill Cove* & West & 2008 & -51.4736 & -59.9764 & + & - & - & Fowler (2013) \\
\hline House Creek & West & 1999 & -51.6097 & -59.5267 & + & + & + & McDowall et al. (2001) \\
\hline House Stream & West & 2012 & -51.6116 & -59.5221 & + & + & + & Fowler (2013) \\
\hline Lake Sulivan, Outflow & West & 2009 & -51.7922 & -60.2111 & - & + & + & Ross (2009) \\
\hline Lake Sulivan North & West & 2011 & -51.8167 & -60.1941 & - & + & + & Fowler (2013) \\
\hline Lake Sulivan North Outflow & West & 1999 & -51.8073 & -60.1976 & - & - & + & McDowall et al. (2001) \\
\hline Lake Sulivan South & West & 2011 & -51.8567 & -60.1891 & + & - & + & Fowler (2013) \\
\hline Larger Stream, Hill Cove & West & 1999 & -51.4945 & -60.0843 & - & - & + & McDowall et al. (2001) \\
\hline Leicester Stream & West & 2009 & -51.9084 & -60.2682 & - & - & + & Ross (2009) \\
\hline Main Point Creek & West & 2009 & -51.4474 & -59.8757 & - & - & + & Ross (2009) \\
\hline Many Branches Stream & West & 1999 & -51.5303 & -59.5083 & + & - & + & McDowall et al. (2001) \\
\hline Mickey Doolan's Ditch & West & 1999 & -51.9292 & -60.1703 & - & - & + & McDowall et al. (2001) \\
\hline Mt Adam Stream & West & 1999 & -51.6355 & -60.0802 & + & - & - & McDowall et al. (2001) \\
\hline Mt Donald Pond Inflow & West & 1999 & -51.5643 & -60.1720 & + & - & - & McDowall et al. (2001) \\
\hline Neil Clark Nature Reserve & West & 2018 & -51.6324 & -59.5452 & + & - & NA & Minett (unpubl.) \\
\hline Poncho Valley Stream & West & 2012 & -51.9736 & -60.4357 & - & + & + & Fowler (2013) \\
\hline Port Howard/Warrah* & West & 1999 & -51.4554 & -59.6245 & + & - & - & McDowall et al. (2001) \\
\hline Port Stephens* & West & 2009 & -52.0980 & -60.8321 & - & - & + & Ross (2009) \\
\hline River Doyle & West & 2009 & -51.7588 & -60.1845 & - & + & + & Ross (2009) \\
\hline Rous Creek Stream & West & 2009 & -51.7006 & -60.6122 & - & - & + & Ross (2009) \\
\hline Skull Pass Stream & West & 1999 & -51.5444 & -59.6095 & + & - & - & McDowall et al. (2001) \\
\hline Stewart's Brook & West & 2009 & -52.0482 & -60.6826 & - & + & + & Ross (2009) \\
\hline Stream by Mt Rosalie House & West & 2009 & -51.4856 & -59.3685 & - & - & + & Ross (2009) \\
\hline Stud Paddock Stream & West & 1999 & -51.9416 & -60.0497 & - & - & + & McDowall et al. (2001) \\
\hline
\end{tabular}




\begin{tabular}{|c|c|c|c|c|c|c|c|c|}
\hline $\begin{array}{l}\text { Teal House River } \\
\text { Table S2 (cont). }\end{array}$ & West & 2018 & -51.6194 & -60.1103 & + & - & $\mathrm{NA}$ & Minett (unpubl.) \\
\hline Sample Site & Island & $\begin{array}{l}\text { Date last } \\
\text { sampled }\end{array}$ & Lat. & Long. & $S t$ & $A p$ & $G m$ & Reference \\
\hline Teal Ponds \& Waterfall Stream & West & 1999 & -51.6557 & -60.0672 & + & - & + & McDowall et al. (2001) \\
\hline Top Hog Ground Stream & West & 1999 & -51.6711 & -59.9714 & + & - & - & McDowall et al. (2001) \\
\hline Unnamed Stream & West & 1999 & -51.5443 & -59.5602 & + & - & - & McDowall et al. (2001) \\
\hline Unnamed Stream & West & 1999 & -51.9092 & -60.2030 & + & - & - & McDowall et al. (2001) \\
\hline Unnamed Stream & West & 2012 & -51.6098 & -59.8563 & + & - & - & Fowler (2013) \\
\hline Unnamed Stream, Hill Cove & West & 1999 & -51.5053 & -60.1034 & - & - & + & McDowall et al. (2001) \\
\hline Unnamed Stream, Hill Cove & West & 1999 & -51.4928 & -60.0587 & + & - & - & McDowall et al. (2001) \\
\hline Warrah River & West & 1999 & -51.5598 & -59.7581 & + & - & - & McDowall et al. (2001) \\
\hline Waterfall Stream & West & 2009 & -51.3817 & -60.5421 & - & - & + & Ross (2009) \\
\hline Weedy Outlet & West & 1999 & -51.8548 & -60.1980 & + & - & + & McDowall et al. (2001) \\
\hline West Lagoons & West & 2013 & -51.4421 & -60.0817 & - & + & + & Fowler (2013) \\
\hline Whisky Creek & West & 2009 & -52.0546 & -60.7896 & - & + & - & Ross (2009) \\
\hline
\end{tabular}


Table S3. Predictors used to generate a species distribution model of brown trout in the Falkland Islands. Predictors shown in bold had a $\mathrm{VIF}<3$ and were included in the model.

\begin{tabular}{|c|c|c|}
\hline Predictor & Description & Source \\
\hline \multicolumn{3}{|c|}{ Anthropogenic predictors } \\
\hline Eucl_dist_inv & $\begin{array}{l}\text { Euclidean distance to nearest } \\
\text { invaded site in a straight line }(\mathrm{km})\end{array}$ & Own creation \\
\hline Coast_dist_inv & $\begin{array}{l}\text { Distance to nearest invaded site } \\
\text { around the coast }(\mathrm{km})\end{array}$ & Own creation \\
\hline Eucl_dist_intro & $\begin{array}{l}\text { Euclidean distance to nearest } \\
\text { introduction site in a straight line }(\mathrm{km})\end{array}$ & Own creation \\
\hline Coast_dist_intro & $\begin{array}{l}\text { Distance to nearest introduction site } \\
\text { around the coast }(\mathrm{km})\end{array}$ & Own creation \\
\hline Intro_site & Introduction site (y/n) & Table S1 \\
\hline Intro_basin & Introduction basin $(y / n)$ & Table S1 \\
\hline Settle_dist & Distance to nearest settlement $(\mathrm{km})$ & $\begin{array}{l}\text { Own creation, } \\
\text { FIG IMS-GIS Centre }\end{array}$ \\
\hline Road_dist & Distance to nearest road $(\mathrm{km})$ & $\begin{array}{l}\text { Own creation, } \\
\text { FIG IMS-GIS Centre }\end{array}$ \\
\hline Road_cross_no & $\begin{array}{l}\text { Number of river-road crossings in the } \\
\text { river basin }\end{array}$ & $\begin{array}{l}\text { Own creation } \\
\text { FIG IMS-GIS Centre }\end{array}$ \\
\hline Road_cross_dist & $\begin{array}{l}\text { Distance to nearest river-road } \\
\text { crossing }(\mathrm{km})\end{array}$ & Own creation \\
\hline BFL & $\begin{array}{l}\text { Barrier Free Length, length of river } \\
\text { between consecutive culverts }(\mathrm{km})\end{array}$ & Own creation \\
\hline BFL_share & $\begin{array}{l}\text { Proportion of total river length free of } \\
\text { culverts }\end{array}$ & Own creation \\
\hline \multicolumn{3}{|l|}{ Bioclimatic predictors } \\
\hline Ap & $\begin{array}{l}\text { Presence of Aplochiton }(\mathrm{y} / \mathrm{n}) \text {; coded } \\
\text { no if unknown }\end{array}$ & Table S2 \\
\hline EW & East or West Island & Own creation \\
\hline $\begin{array}{l}\text { Slope } \\
\text { Alt }\end{array}$ & $\begin{array}{l}\text { Mean slope of grid cell } \\
\text { Mean altitude of each grid (m) }\end{array}$ & $\begin{array}{l}\text { USGS } \\
\text { USGS }\end{array}$ \\
\hline River_dens & River network in the basin $(\mathrm{km})$ & $\begin{array}{l}\text { Own creation } \\
\text { FIG IMS-GIS Centre }\end{array}$ \\
\hline Flow_accum & $\begin{array}{l}\text { Mean flow accumulation scaled by } \\
\text { max flow accumulation in basin }\end{array}$ & $\begin{array}{l}\text { Own creation } \\
\text { FIG IMS-GIS Centre }\end{array}$ \\
\hline Min_winter_temp & Minimum winter temperature $\left({ }^{\circ} \mathrm{C}\right)$ & FIG IMS-GIS Centre \\
\hline Rain & Annual precipitation (mm) & FIG IMS-GIS Centre \\
\hline LC & Land cover/substrate type & $\begin{array}{l}\text { FIG IMS-GIS Centre } \\
\text { DPLUS065 Project }\end{array}$ \\
\hline
\end{tabular}

